\title{
Japanese telephone shares finance four new institutes
}

Tokyo. An organization set up in 1985 with proceeds from the privatization of the Nippon Telegraph and Telephone Corporation (NTT) - Japan's main domestic telephone company - has announced plans to provide billions of yen over the next five to seven years to support three new institutes that are being established to develop computer network and mobile telecommunications technology.

The Japan Key Technology Centre, which already funds several wealthy semi-private institutes in Japan, also plans to make a large investment in a laboratory that will develop optical techniques for detecting and analysing trace amounts of biomolecules, such as messenger RNA. The ultimate goal of the laboratory is to develop techniques for looking at processes such as gene expression as they occur in living organisms.

The centre is affiliated to the Ministry of Posts and Telecommunications (MPT) and the Ministry of International Trade and Industry (MITI). It receives between $¥ 25$ and $¥ 28$ billion (US\$238 to $\$ 267$ billion) each year from the dividends of NTT shares held by the government, most of which is subsequently invested in research institutes that are supported and run by consortia of private companies.

The best known (and best endowed) of these are the Protein Engineering Research Institute in Osaka, and the Advanced Telecommunications Research Institute International in the emerging Kansai science city which is being built between Osaka, Nara and Kyoto. Both have won international recognition for the high quality of their research (see Nature 359, 577; 1992).

Last week, the centre announced the establishment of five new institutes. In line with the government's recent investments in computer networks, one institute (which will be supported by Fujitsu, NEC and Hitachi) will develop technology for high speed computer networks with transmission rates up to 2.4 gigabits per second, 400 times the present fastest speed of networks in Japan.

Under the centre's standard procedures, it will provide 70 per cent of the institute's $¥ 3.5$ billion annual budget over the next five years. The companies will provide the rest of the money.

Two further institutes will support work on the development of advanced mobile telecommunications systems. One will focus on satellite technology, and the other mainly on land-based systems, including the application of high-temperature superconductors to such systems.

The most novel institute is the Laboratory of Molecular BioPhotonics, headed by the small company Hamamatsu Photonics. The company makes some of the world's most sensitive photon detecting devices, and has been associated with a number of government-funded science projects. The company's giant photomultiplier tubes, for example, are used in the Kamiokande neutrino detector in a mine in Gifu Prefecture (see Nature 365, 596; 1993).

The biophotonics laboratory will open towards the end of the year in a science park in the town of Hamamatsu, between Tokyo and Nagoya, where the company is located. It will develop fluorescent reagents for labelling functional biomolecules, such as messenger RNA, as well as highly sensitive optical detectors that can be used to pinpoint trace quantities of the molecules.

David Swinbanks

\begin{tabular}{|c|c|c|c|}
\hline \multicolumn{4}{|c|}{ New institutes of Japan Key Technology Centre } \\
\hline Institute name* & $\begin{array}{l}\text { Budget } \\
\text { (billion } ¥ \text { ) }\end{array}$ & $\begin{array}{l}\text { Duration } \\
\text { years }\end{array}$ & $\begin{array}{l}\text { Participating } \\
\text { companies }\end{array}$ \\
\hline $\begin{array}{l}\text { Laboratory of Molecular } \\
\text { BioPhotonics }\end{array}$ & 6.4 & 6 & $\begin{array}{l}\text { Hamamatsu Photonics; } \\
\text { Chugai Pharmaceutical; } \\
\text { Toyota; Japan Tobacco; } \\
\text { Nikon }\end{array}$ \\
\hline $\begin{array}{l}\text { Commuter Helicopter Advanced } \\
\text { Technology Institute }\end{array}$ & 8.8 & 7 & $\begin{array}{l}\text { Kawasaki Heavy Industries; } \\
\text { Shimadzu; Teijin; + } 2 \text { others }\end{array}$ \\
\hline $\begin{array}{l}\text { High-speed Network Computer } \\
\text { Technology Institute }\end{array}$ & 3.5 & 5 & NEC; Fujitsu; Hitachi \\
\hline $\begin{array}{l}\text { Next-generation Satellite } \\
\text { Telecommunications and } \\
\text { Broadcasting Systems } \\
\text { Institute }\end{array}$ & 8.4 & 7 & $\begin{array}{l}\text { NEC; Mitsubishi Electric; } \\
\text { Hitachi; Fujitsu; KDD; } \\
\text { Pioneer; Japan Radio; } \\
\text { + } 6 \text { others }\end{array}$ \\
\hline $\begin{array}{l}\text { Mobile Telecommunications } \\
\text { Advanced Technology Institute }\end{array}$ & 2.9 & 6 & $\begin{array}{l}\text { Nippondenso; Alps Electric; } \\
+1 \text { other }\end{array}$ \\
\hline
\end{tabular}

*Translation of tentative name in Japanese

\section{Final agreement on new funding for Framework projects}

Paris. The next five-year Framework research programme of the European Union (EU) overcame its last major obstacle on Monday when the Council of Ministers and representatives of the European Parliament reached agreement on a single text.

This is the first time that the conciliation procedures between the two political bodies, which were introduced under the terms of the Maastricht agreement, have been tested.

Last autumn, the parliament asked for a budget of ECU13.7 billion (\$US15.2 billion) for the Framework programme for the period 1994-98 inclusive. In contrast, however, various member states, including both Britain and Germany, argued for a figure as low as ECU8 billion.

In December, the Council of Ministers agreed on a proposal that would provide an immediate commitment to spend ECU12 billion, while 'freezing' an extra ECU1 billion. But last month, parliament rejected this solution and argued for a definite commitment to an extra ECU400 million.

The compromise reached on Monday means that the Fourth Framework will definitely receive ECU12.3 billion, with a decision on an extra 0.7 billion to be taken in 1996. The enlargement of the EU to include Finland, Sweden and Austria will swell the Framework budget by an extra 6 per cent.

The parliament also won a commitment from the council that a significant proportion of the extra ECU300 million will be spent on technology transfer - the application of research results. Despite growing calls for the EU to spend more on this activity, member states had previously cut the money proposed for it from 4.6 per cent of the total, as suggested by the European Commission, to only 2.5 per cent.

The conciliation committee also agreed a figure of ECU900 million for the EU's four Joint Research Centres (JRCs). Parliament had proposed ECU910 million for the JRCs, and the council ECU885 million. Parliament refused to accept that the centres should be made to compete for 22 per cent of their budget, even though this was reduced from the council's original suggestion of 24 per cent.

But it is now virtually certain that the Framework programme will be adopted quickly. Under the new procedures of the Maastricht agreement, both council and parliament must approve a joint text of the Framework budget.

There had been widespread fears that, if the complex approval procedure was not completed before June, when elections to the parliament are due to be held, it would have to begin again in 1995 .

Declan Butler 